\title{
GUIDELINES FOR THE VACCINATION OF \\ DOGS AND CATS
}

\section{COMPILED BY THE VACCINATION GUIDELINES GROUP (VGG) OF THE WORLD SMALL ANIMAL VETERINARY ASSOCIATION (WSAVA)}

\section{Members of the VGG}

\author{
M. J. DAY
}

Division of Veterinary Pathology, Infection and Immunity, University of Bristol, UK

M. C. Horzinek (Chairman)

(Formerly) Department of Microbiology, Virology Division, University of Utrecht, The Netherlands

R. D. SCHULTZ

Department of Pathobiology, University of Wisconsin-Madison, USA

\section{CONTENTS}

Executive Summary

Introduction

Current Issues in Small Animal Vaccinology

Canine Vaccination Guidelines.

Feline Vaccination Guidelines

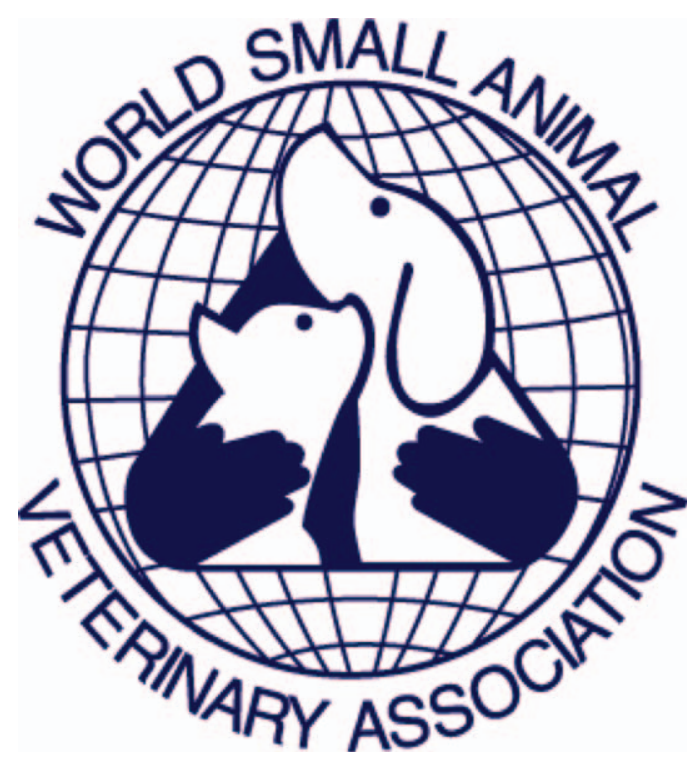




\section{EXECUTIVE SUMMARY}

The WSAVA Vaccination Guidelines Group (VGG) was convened in order to develop guidelines for the vaccination of dogs and cats that have global application. The VGG acknowledges the valuable foundation to their deliberations provided by the recent canine and feline vaccine guidelines from the United States of America (USA). The VGG recognises that the keeping of pet small animals is subject to significant variation in practice and associated economics throughout the world, and that vaccination recommendations that might apply to a developed country, may not be appropriate for a developing country. Despite this, the VGG strongly recommends that wherever possible ALL dogs and cats receive the benefit of vaccination. This not only protects the individual animal, but provides optimum "herd immunity" that minimises the likelihood of outbreak of infectious disease.

With this background in mind, the VGG has defined core vaccines which ALL dogs and cats, regardless of circumstances, should receive. Core vaccines protect animals from severe, life-threatening diseases which have global distribution. Core vaccines for dogs are those that protect from canine distemper virus (CDV), canine adenovirus (CAV) and canine parvovirus (CPV). Core vaccines for cats are those that protect from feline parvovirus (FPV), feline calicivirus (FCV) and feline herpesvirus (FHV). In areas of the world where rabies virus infection is endemic, vaccination against this agent should be considered core for both species, even if there is no legal requirement for routine vaccination.

The VGG recognises that maternally derived antibody (MDA) significantly interferes with the efficacy of most current core vaccines administered to pups and kittens in early life. As the level of MDA varies significantly between litters, the VGG recommends the administration of three vaccine doses to pups and kittens, with the final of these being delivered at 16 weeks of age or above. In cultural or financial situations where a pet animal may only be permitted the benefit of a single vaccination, that vaccination should be with core vaccines at 16 weeks of age or above.

The VGG supports the development and use of simple in-practice tests for determination of sero-conversion (antibody) following vaccination.

Vaccines should not be given needlessly. Core vaccines should not be given any more frequently than every three years after the 12 month booster injection following the puppy/kitten series.

The VGG has defined non-core vaccines as those that are required by only those animals whose geographical location, local environment or lifestyle places them at risk of contracting specific infections. The VGG has also classified some vaccines as not recommended (where there is insufficient scientific evidence to justify their use) and has not considered a number of minority products which have restricted geographical availability or application.

The VGG strongly supports the concept of the "annual health check" which removes the emphasis from, and client expectation of, annual revaccination. The annual health check may still encompass administration of selected non-core vaccines which are generally administered annually.

The VGG has considered the use of vaccines in the shelter environment, again recognising the particular nature of such establishments and the financial constraints under which they operate. The VGG minimum shelter guidelines are simple: that all dogs and cats entering such an establishment should be vaccinated before, or at the time of entry, with core vaccine only. Where finances permit, repeated core vaccination should be administered as per the schedules defined in the guidelines.

The VGG recognises the importance of adverse reaction reporting schemes but understands that these are variably developed in different countries. Wherever possible, veterinarians should be actively encouraged to report all possible adverse events to the manufacturer and/or regulatory authority to expand the knowledge base that drives development of improved vaccine safety.

These fundamental concepts proposed by the VGG may be encapsulated in the single strap-line:

We should aim to vaccinate every animal, and to vaccinate each individual less frequently

\section{INTRODUCTION}

One of the greatest successes of modern veterinary science has been the control of infectious disease through the development and implementation of vaccination programmes. This success is typified by the rapid decline in the prevalence of key canine infectious diseases (caused by canine distemper virus [CDV], canine adenovirus [CAV] and canine parvovirus [CPV]) following the introduction of efficacious modified live virus vaccines. Similar effects relate to the introduction of feline vaccines, with clear reduction in mortality caused by feline parvovirus (FPV; feline panleukopenia) and morbidity caused by feline calicivirus (FCV) and herpesvirus (FHV) infections. However, the success of these vaccines cannot be a cause for complacency, and indeed vaccine-related issues have featured high on the agenda of the veterinary profession over the past decade. There are many challenges remaining in small animal vaccinology, and in 2006 the WSAVA Vaccination Guidelines Group (VGG) was convened with the specific remit of taking a global 
perspective on issues surrounding the practice of vaccination of dogs and cats. The VGG has met formally on three occasions and corresponded electronically between these meetings, and this document is the result of these deliberations. The VGG guidelines are built on those developed by the American Animal Hospital Association (AAHA) Canine Vaccine Task Force and the American Association of Feline Practitioners (AAFP) Feline Vaccine Advisory Panel. Based upon a consensus among experts, these recommendations reflect a combination of opinion, experience, and scientific data, published and unpublished. The present vaccination guidelines are intended for the general veterinary practice and the shelter environment; they do not represent a standard of care or set of legal parameters. They have been drafted with the objective of educating and informing the profession and to recommend rational vaccine use for individual pets and $\mathrm{dog} / \mathrm{cat}$ populations.

\section{CURRENT ISSUES IN SMALL ANIMAL VACCINOLOGY}

If vaccination has been so successful, then why is it necessary to continually re-evaluate vaccination practice? There is little doubt that in most developed countries the major infectious diseases of dogs and cats are considered at best uncommon in the pet population, but there do remain geographical pockets of infection and sporadic outbreaks of disease occur, and the situation regarding feral or shelter populations is distinctly different to that in owned pet animals. However, in many developing countries these key infectious diseases remain as common as they once were in developed nations and a major cause of mortality in small animals. Although it is difficult to obtain accurate figures, even in developed countries it is estimated that only $30-50 \%$ of the pet animal population is vaccinated, and this is significantly less in developing nations. In small animal medicine, we have been slow to grasp the concept of 'herd immunity' that vaccination of individual pet animals is important, not only to protect the individual, but to reduce the number of susceptible animals in the regional population, and thus the prevalence of disease.

A second major concept regarding vaccination of dogs and cats has been the recognition that we should aim to reduce the 'vaccine load' on individual animals in order to minimise the potential for adverse reactions to vaccine products. For that reason we have seen the development of vaccination guidelines based on a rational analysis of the vaccine requirements for each pet, and the proposal that vaccines be considered 'core' and 'non-core' in nature. To an extent this categorisation of products has been based on available scientific evidence and personal experience - but concerted effort to introduce effective companion animal disease surveillance on a global scale would provide a more definitive basis on which to recommend vaccine usage. In parallel with the categorisation of vaccines has been the push towards marketing products with extended duration of immunity (DOI), to reduce the unnecessary administration of vaccines and thereby further improve vaccine safety. Both of these changes have necessitated a frame-shift in the mindset of veterinary practitioners in a culture in which both veterinarian and client have become subservient to the mantra of annual vaccination.

The following VGG guidelines are prepared when considering the optimum model of a committed pet owner, willing and able to bring their animal to the veterinarian, for the full recommended course of vaccination. The VGG is aware that there are less committed pet owners and countries where severe financial constraints will determine the nature of the vaccine course that will be administered. In situations where, for example, a decision must be made that an individual pet may have to receive only a single core vaccination during its lifetime, the VGG would emphasise that this should optimally be given at a time when that animal is most capable of responding immunologically, i.e. at the age of 16 weeks or greater.

The VGG has additionally considered vaccination in the shelter situation. The guidelines that we have proposed are those that we consider provides the optimum level of protection for these highly susceptible animals. The VGG also recognises that many shelters run with limited financial support which may constrain the extent of vaccination used. The minimum vaccination protocol in this situation would be a single administration of core vaccines at or before the time of admission to the shelter.

This document seeks to address these current issues in canine and feline vaccinology, and to suggest practical measures by which the veterinary profession may move towards more rational use of vaccination in these species. The most important message of the VGG is therefore encapsulated in the single strap-line:

We should aim to vaccinate every animal, and to vaccinate each individual less frequently

\section{CANINE VACCINATION GUIDELINES}

\section{VACCINATION OF INDIVIDUAL DOGS}

\section{The Basic Immunisation Schedule}

Guidelines and recommendations for core (recommended), non-core (optional), and not recommended vaccines for the general veterinary practice are given in Table 1 . The VGG considers that a core vaccine is one that all puppies throughout the world must 
receive in order to provide protection against infectious diseases of global significance. The VGG recognises that particular countries will identify additional vaccines that they consider core. A particular example of a vaccine that may be considered core in only some countries is that against rabies virus. In a geographical area in which this infection is endemic all dogs should be routinely vaccinated for the protection of both the pet and human populations. In some countries, mandatory rabies vaccination is a legal requirement, and is generally also required for international pet travel. Non-core vaccines are those that are licensed for the dog and whose use is determined on the basis of the animal's geographical and lifestyle exposure and an assessment of risk-benefit ratios. Not recommended vaccines are those for which there is little scientific justification for their use.

\section{Pup Vaccination and the 12 Month Booster}

Most pups are protected by maternally derived antibodies (MDA) in the first weeks of life. In general, passive immunity will have waned by 8 to 12 weeks of age to a level that allows active immunisation. Pups with poor MDA may be vulnerable (and capable of responding to vaccination) at an earlier age, while others may possess MDA at such high titres that they are incapable of responding to vaccination until $\geq 12$ weeks of age. No single primary vaccination policy will therefore cover all possible situations. The recommendation of the VGG is for initial vaccination at 8 to 9 weeks of age followed by a second vaccination 3 to 4 weeks later, and a third vaccination given between 14 to 16 weeks of age. By contrast, at present many vaccine data sheets recommend an initial course of two injections. Some products are also licensed with a ' 10 week finish' designed such that the second of two vaccinations is given at 10 weeks of age. The rationale behind this protocol is to permit 'early socialisation' of pups. The VGG recognises that this is of great benefit to the behavioural development of dogs. Where such protocols are adopted, great caution should still be maintained by the owner - allowing restricted exposure of the pup to controlled areas and only to other pups that are healthy and fully vaccinated.

In immunological terms, the repeated injections given to pups in their first year of life do not constitute boosters. They are rather attempts to induce a primary immune response by injecting the attenuated virus (of modified live virus [MLV] vaccines) into an animal devoid of neutralising antibody, where it must multiply to be processed by an antigen presenting cell and stimulate antigenspecific $\mathrm{T}$ and $\mathrm{B}$ lymphocytes. In the case of killed (inactivated) vaccines, MDA may also interfere with this immunological process by binding to and 'masking' the relevant antigens.

All dogs should receive a first booster 12 months after completion of the primary vaccination course. The VGG redefines the basic immunisation protocol as the ensemble of the pup regime plus this first booster. The 12 month booster will also ensure immunity for dogs that may not have adequately responded to the pup vaccination course.

\section{Revaccination of Adult Dogs}

Dogs that have responded to vaccination with MLV core vaccines maintain a solid immunity (immunological memory) for many years in the absence of any repeat vaccination. Following the 12 month booster, subsequent revaccinations are given at intervals of three years or longer, unless special conditions apply. It should be emphasised that the considerations given above do not generally apply to killed core vaccines nor to the optional vaccines, and particularly not to vaccines containing bacterial antigens. Thus Leptospira, Bordetella and Borrelia (Lyme disease) products require more frequent boosters for reliable protection.

\section{Serological Testing to Monitor Immunity to Canine Vaccines}

Antibody tests are useful for monitoring immunity to CDV, canine parvovirus-2 (CPV-2), canine adenovirus-1 (CAV-1), and rabies virus. Antibody assays for CDV and CPV-2 are the tests of greatest benefit in monitoring immunity, especially after the puppy vaccination series. During recent years, many laboratories have standardised their methodologies for such testing. There are legal requirements for rabies antibody testing for pet travel between some countries.

In-practice testing will probably become more popular as soon as rapid, simple, reliable and cost-effective assays are more widely available. A negative test result indicates that the animal has little or no antibody, and that revaccination is recommended. Some of these dogs are in fact immune (false-negative), and their revaccination would be unnecessary. A positive test result on the other hand would lead to the conclusion that revaccination is not required. This is why robust yes/no answers must be provided by any assay. With CDV and/or CPV-2 tests, an animal with a negative result, regardless of the test used, should be considered as having no antibody and susceptible to infection.

On completion of the puppy series at 14 to 16 weeks of age, an animal should have a positive test result, provided the serum sample is collected 2 or more weeks after vaccination. Seronegative animals should be revaccinated and retested. If it again tests negative, it should be considered a non-responder that is possibly incapable of developing protective immunity.

Testing for antibody is presently the only practical way to ensure that a puppy's immune system has recognised the vaccinal antigen. Vaccines may fail for various reasons: 


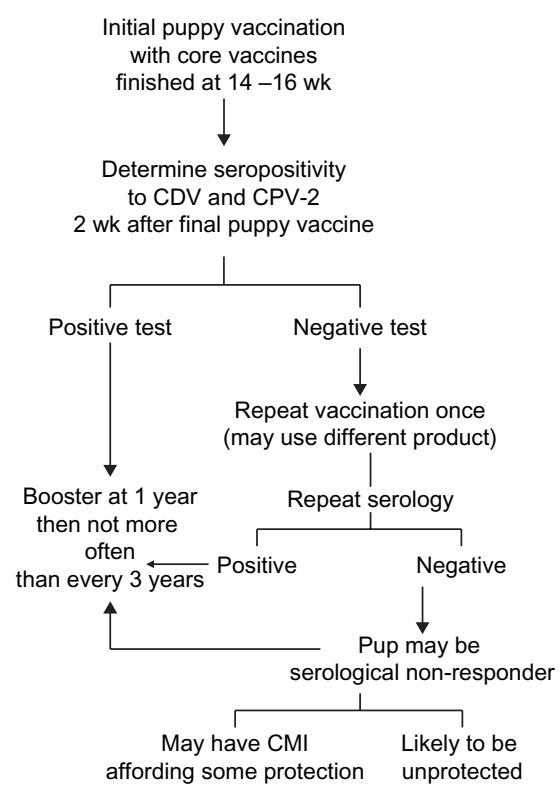

FIG 1. Flow chart for serological testing of puppies. CMI, Cell-mediated immunity

\section{(1) MDA neutralises the vaccine virus}

This is the most common reason for vaccination failure. When the last vaccine dose is given at $\geq 12$ weeks of age however, MDA should have decreased to a low level, and active immunisation will succeed in most puppies (>98\%).

(2) The vaccine is poorly immunogenic

Poor immunogenicity may reflect a range of factors from the stage of vaccine manufacture to administration to the animal. For example, the virus strain, its passage history or production errors in the manufacture of a particular batch of product may be a cause of vaccine failure. Post-manufacture factors such as incorrect storage or transportation (interrupted cold chain) and handling (disinfectant use) of the vaccine in the veterinary practice, may result in inactivation of an MLV product.

(3) The animal is a poor responder (its immune system intrinsically fails to recognise the vaccinal antigens)

If an animal fails to develop an antibody response after repeated revaccination, it should be considered a non-responder. Because immunological non-responsiveness is genetically controlled in other species, certain breeds of dogs have been suspected to be poor-responders. It is believed (but unproven) that the high susceptibility to CPV-2 recognised in certain Rottweilers and Dobermans during the 1980s (regardless of their vaccination history) was due to a high prevalence of non-responders. In the USA today, these two breeds seem to have no greater numbers of non-responders than other breeds, possibly because carriers of the genetic trait may have died from CPV-2. This may not be true for other countries. For example, in the UK and Germany, the non-responder phenotype remains prevalent amongst Rottweilers.

\section{Serological Testing to Determine the Duration of Immunity (DOI)}

Most vaccinated dogs will have a persistence of serum antibody (against core vaccine antigens) for many years. Immunologically, this antibody reflects the function of a distinct population of long-lived plasma cells (memory effector B cells). Induction of immunological memory is the primary objective of vaccination. For core vaccines there is excellent correlation between the presence of antibody and protective immunity and there is long DOI for these products. This correlation does not exist for many of the non-core vaccines and the DOI related to these products necessitates more frequent revaccination intervals.

Antibody tests can be used to demonstrate the DOI after vaccination with core vaccines. It is known that dogs often maintain protective antibody to CDV, CPV-2, CAV-1, and CAV-2 for three or more years and numerous experimental studies support this observation. Therefore, when antibody is absent (irrespective of the serological test used) the dog should be revaccinated unless there is a medical basis for not so doing. Antibody determinations to other vaccine components are of limited value because of the short time period these antibodies persist (e.g., Leptospira products) or the lack of correlation between serum antibody and protection (e.g. canine parainfluenza). Important considerations in performing antibody tests are the cost and the time to obtain results.

The VGG recognises that at present such serological testing has limited availability and might be relatively expensive. However, the principles of 'evidence-based veterinary medicine' would dictate that testing for antibody status (for either pups or adult dogs) is better practice than simply administering a vaccine booster on the basis that this should be 'safe and cost less'. In response to these needs, more rapid, cost-effective tests are being developed. 


\section{FELINE VACCINATION GUIDELINES}

\section{VACCINATION OF INDIVIDUAL CATS}

\section{The Basic Immunisation Schedule}

Guidelines and recommendations for core (recommended), non-core (optional) and not generally recommended vaccines for the general veterinary practice are given in Table 3 . A particular example of a vaccine that may be considered core in only some countries is that against rabies virus. In a geographical area in which this infection is endemic all cats should be routinely vaccinated for the protection of both the pet and human populations. In some countries, mandatory rabies vaccination is a legal requirement, and is generally also required for international pet travel. In terms of feline core vaccines it is important to realise that the protection afforded by the feline calicivirus (FCV) and feline herpesvirus (FHV) vaccines will not provide the same efficacy of immunity as seen with the feline panleukopenia (feline parvovirus; FPV) vaccines. Thus the feline core vaccines should not be expected to give the same robust protection, nor the duration of immunity, as seen with canine core vaccines.

Although the FCV vaccines have been designed to produce cross-protective immunity against severe clinical disease, there are multiple strains of FCV and it is possible for infection and mild disease to occur in the vaccinated animal. With respect to FHV, it should be remembered that there is no herpesvirus vaccine than can protect against infection with virulent virus, and that virulent virus will become latent and may be reactivated during periods of severe stress. The reactivated virus may cause clinical signs in the vaccinated animal or the virus can be shed to susceptible animals and cause disease in them.

\section{Kitten Vaccination and the 12 Month Booster}

As discussed for pups, most kittens are protected by MDA in the first weeks of life. However, without serological testing, the level of protection and the point at which the kitten will become susceptible to infection and/or can respond immunologically to vaccination is unknown. This is related to the level of maternal antibody and variation in uptake of MDA between litters. In general, MDA will have waned by 8 to 12 weeks of age to a level that allows an active immunological response, and an initial vaccination at 8 to 9 weeks of age followed by a second vaccination 3 to 4 weeks later is commonly recommended. Many vaccines carry data sheet recommendations to this effect. However, kittens with poor MDA may be vulnerable (and capable of responding to vaccination) at an earlier age, while others may possess MDA at such high titres that they are incapable of responding to vaccination until sometime after 12 weeks of age. Therefore the VGG endorses the recent recommendation made in the AAFP guidelines of administering the final kitten dose at 16 weeks or older.

All kittens should receive the core vaccines. A minimum of three doses - one at 8 to 9 weeks of age, a second 3 to 4 weeks later and a final dose at 16 weeks of age or older should be administered. Cats that respond to MLV core vaccines maintain immunity for many years, in the absence of any repeat vaccination.

\section{Revaccination of Adult Cats}

All cats should receive a first booster 12 months after completion of the kitten vaccination course (this will ensure adequate vaccineinduced immunity for cats that may not have adequately responded to the primary course). Following this first booster, subsequent revaccinations are given at intervals of three years or longer, unless special conditions apply. Adult cats of unknown vaccination status should receive a single initial MLV core vaccine injection followed by a booster vaccination one year later.

Cats that have responded to vaccination with MLV core vaccines maintain a solid immunity (immunological memory) for many years in the absence of any repeat vaccination. It should be emphasised that the considerations given above do not generally apply to killed core vaccines nor to the optional vaccines, and particularly not to vaccines containing bacterial antigens. Thus Chlamydophila and Bordetella products require more frequent boosters for reliable protection.

\section{Serological Testing}

At this point in time there is limited availability of serological testing for vaccinal antibody responses in the cat, and tests for the detection of FPV antibody in this context are still under development. Once these are available, the VGG would endorse their use in the same way as described above for the dog.

\section{VACCINATION IN THE SHELTER ENVIRONMENT}

An animal shelter is a holding facility for animals usually awaiting adoption, rescue, or reclaim by owners. In general, animal shelters are characterised by a random source population with a mostly unknown vaccination history, high population turnover, and high infectious disease risk. The term "shelter" encompasses situations ranging from sanctuaries that possess a stable population, to facilities that admit hundreds of animals per day, to rescue and foster homes that care for multiple individuals or litters at 
any given time. Just as the vaccination strategy varies with each individual pet, there is no one-size-fits-all strategy for vaccinating shelter animals. The likelihood of exposure and the potentially devastating consequences of infection necessitate a clearly defined shelter vaccination program.

Shelter medicine differs from individual care in that it has to practice in an environment where eradication of infectious disease cannot be attained. It is possible, however, to minimise the spread of infections within a high-density, high-risk population and maintain the health of not yet infected individuals. When the overall purpose is to place healthy pets into welcoming homes, the time and effort dedicated to controlling infectious disease is only one of many variables in the complex shelter medicine and husbandry equation. The recommendations provided here attempt to address some shelter-unique issues as they pertain to vaccination and disease control.

Guidelines and recommendations for vaccines to be used in shelters are given in Tables 2 and 4. If unambiguous documentation of vaccination is provided for an animal at the time of admission to a shelter, there is no reason to revaccinate.

The VGG discriminates between a shelter and a boarding kennel/cattery. The latter are facilities where fully vaccinated animals may be temporarily boarded for relatively short periods of time (e.g. when owners are on vacation). It should be a requirement of entry to any such facility that the individual dog or cat is fully vaccinated with core products given according to the guidelines presented herein. The use of non-core vaccines against respiratory infections is also appropriate under these circumstances.

\section{GENERAL CONSIDERATIONS}

\section{Comprehensive Individual Care Beyond Vaccination}

In the past, veterinary practice has benefited from the annual administration of vaccines. By encouraging owners to bring their pets yearly for vaccination, veterinarians were able to recognise and treat disease earlier than might otherwise have been the case. In addition, the annual visit provided an opportunity to inform clients of important aspects of canine and feline health care.

Unfortunately, many clients have come to believe that vaccination is the most important reason for annual veterinary visits. Veterinarians are now concerned that a reduction in vaccination frequency will cause clients to forgo the annual visits and that the quality of care will diminish. It is therefore essential that veterinarians stress the importance of all aspects of a comprehensive individualised health care program. Emphasis should be placed on a detailed vaccination interview, a comprehensive physical examination by the veterinarian, and individualised patient care. The importance of dental care, proper nutrition, appropriate diagnostic testing and the control of parasites and of zoonotic diseases should also be addressed during evaluation of each pet. Behaviour concerns should be discussed, as well as the necessity for more frequent examination of young and geriatric animals.

The yearly health care/vaccination interview should assess the need for non-core vaccines for the pet. The practitioner should explain to the client the types of vaccines available, their potential benefits and risks, and their applicability to the particular animal, given its lifestyle and risk of exposure. Whilst an animal might not receive core vaccination every year, most non-core vaccines do require annual administration - so owners will continue to see their animal vaccinated annually. The regional incidence and risk factors for various infectious diseases should also be discussed. Ways to reduce the impact of acquired disease (e.g., avoiding overcrowding, improving nutrition, and restricting access to infected animals) should also be reviewed.

Vaccinations should be considered as only one component of a comprehensive preventative health care plan individualised based on the age, breed, health status, environment (potential exposure to harmful agents), lifestyle (contact with other animals), and travel habits of the pet.

Age has a significant effect on the preventative health care needs of any given individual. Puppy/kitten programs have traditionally focused on vaccinations, parasite control, and neutering. Today, opportunity exists to incorporate behaviour counselling and zoonotic disease management. For the aging pet, senior care programs are becoming increasingly popular. Nutritional, dental disease, and parasite control assessment and counselling should take place on an individualised basis throughout the life of the pet.

Certain breeds are predisposed to various diseases. Early detection (particularly of neoplasia) and management of breed-associated disease can significantly improve the quality of the animal's entire life. Pets with chronic medical conditions warrant periodic scheduled medical progress examinations and testing. Animals receiving certain medications also warrant therapeutic monitoring of blood levels and/or organ systems. The development of recheck protocols for chronic diseases and medications, which can be included in reminder systems, can greatly improve client compliance and, accordingly, pet care.

The environment in which a pet resides can profoundly affect its health status and should be assessed during annual health care visits in order to define risk factors and develop appropriate preventative measures.

By determining the extent to which dogs and cats come into contact with other animals in unobserved circumstances, veterinarians can assess the need for non-core vaccinations. Dogs that visit kennels, grooming salons, common areas, and wooded, tick-infested areas are potentially at greater risk from certain infectious diseases than dogs that do not frequent these areas. 
Just as the human population has become more mobile, so has the pet population, resulting in potential exposure to infectious agents, parasites, and environmental hazards not found in the home environment. Determining past and anticipated future travel during each visit allows for greater individualisation of preventative care and diagnostic testing plans.

\section{Medical Record Documentation}

At the time of vaccine administration, the following information should be recorded in the patient's permanent medical record:

- date of vaccine administration,

- identity (name, initials, or code) of the person administering the vaccine,

- vaccine name, lot or serial number, expiry date, and manufacturer

- site and route of vaccine administration.

The use of peel-off vaccine labels and stamps that imprint the medical record with the outline of a pet facilitates this type of record keeping which is mandatory in some countries. Adverse events should be recorded in a manner that will alert all staff members during future visits. Informed consent should be documented in the medical record in order to demonstrate that relevant information was provided to the client and that the client authorised the procedure. At the very least, this notation should indicate that a discussion of risks and benefits took place prior to vaccination.

\section{Adverse Events}

Adverse events are defined as any side effects or unintended consequences (including lack of protection) associated with the administration of a vaccine product. They include any injury, toxicity, or hypersensitivity reaction associated with vaccination, whether or not the event can be directly attributed to the vaccine. Adverse events should be reported, whether their association with vaccination is recognised or only suspected. A vaccine adverse event report should identify the product(s) and animal(s) involved in the event(s) and the individual submitting the report.

Reporting field observations of unexpected vaccine performance is the most important means by which the manufacturer and the regulatory agency are alerted to potential vaccine safety or efficacy problems that may warrant further investigation. The purpose of pre-licensure safety studies is to detect relatively common adverse events. Rare adverse events will be detected only by post-marketing surveillance through analysis of reported adverse events. Adverse events should be reported to the manufacturer and/or the local regulatory authority. The VGG recognises that there is gross under-reporting of vaccine-associated adverse events which impedes knowledge of the ongoing safety of these products. The VGG would actively encourage all veterinarians to participate in such surveillance schemes.

If a particular adverse event is well documented, reporting serves to provide a baseline against which future reports can be compared. In addition, reported adverse events can lead to detection of previously unrecognised reactions, detection of increases in known reactions, recognition of risk factors associated with reactions, identification of vaccine lots with unusual events or higher numbers of adverse events, and can further stimulate clinical, epidemiological, or laboratory studies. Therefore, veterinarians are encouraged to report any clinically significant adverse event occurring during or after administration of any licensed vaccine. Reporting a vaccine adverse event is not an indictment against a particular vaccine; it facilitates review of temporally associated conditions and adds to the safety database of the product.

\section{Acknowledgments}

The work of the Vaccination Guidelines Group has been generously sponsored by Intervet. The VGG is an independent group of academic experts who have formulated these guidelines without consultation with industry.

\section{References}

Paul, M. A., Carmichael, L. E., Childers, H., Cotter, S., Davidson, A., Ford, R., Hurley, K. F., Roth, J. A., Schultz, R. D., Thacker, E. \& Welborn, L. (2006) 2006 AAhA canine vaccine guidelines. Journal of the American Animal Hospital Association, 42, 80-89

Richards, J. R., Elston, T. H., Ford, R. B., Gaskell, R. M., Hartmann, K., Hurley, K., Lappin, M. R., Levy, J. R., Rodan, I., Scherk, M., Schultz, R. D. \& Sparkes, A. H. (2006) The 2006 American Association of Feline Practitioners Feline Vaccine Advisory Panel Report. Journal of the American Veterinary Medical Association, 229, 14051441 


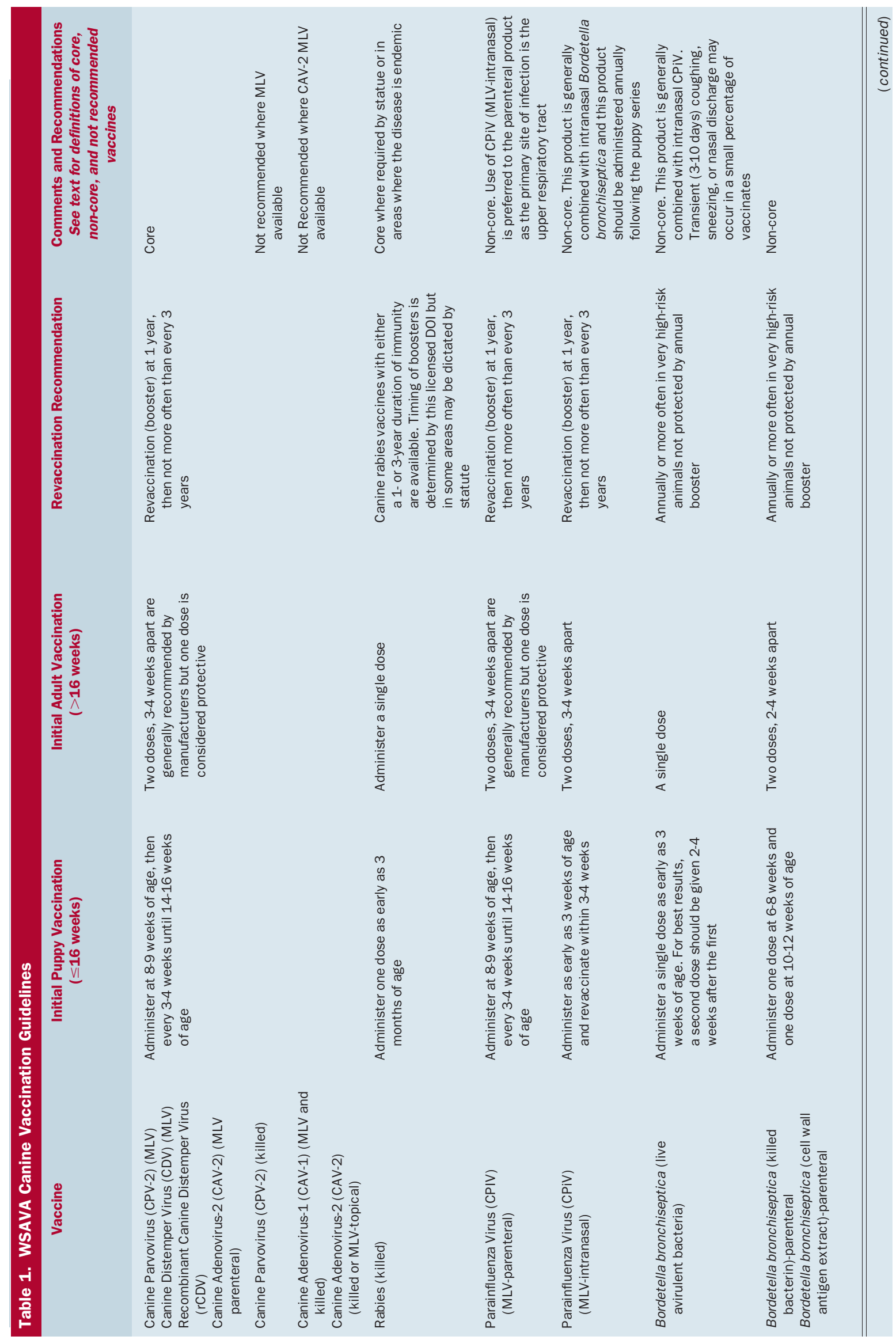




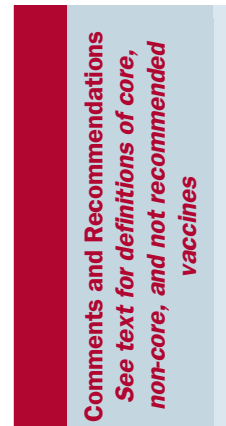

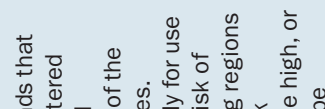

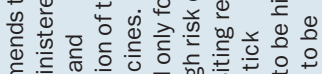

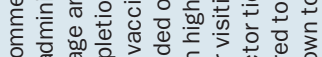

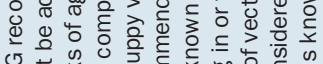

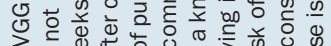

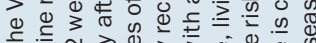

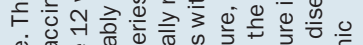

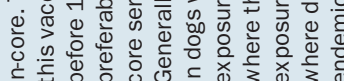

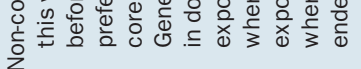
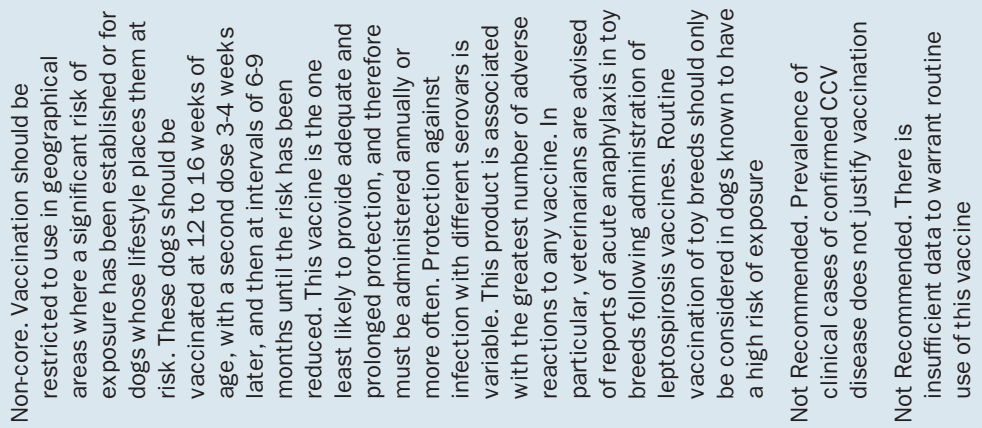

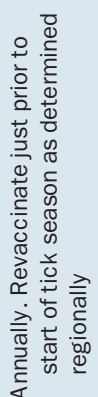

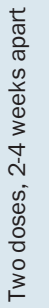

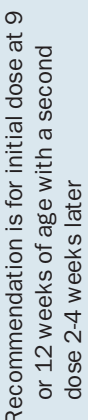
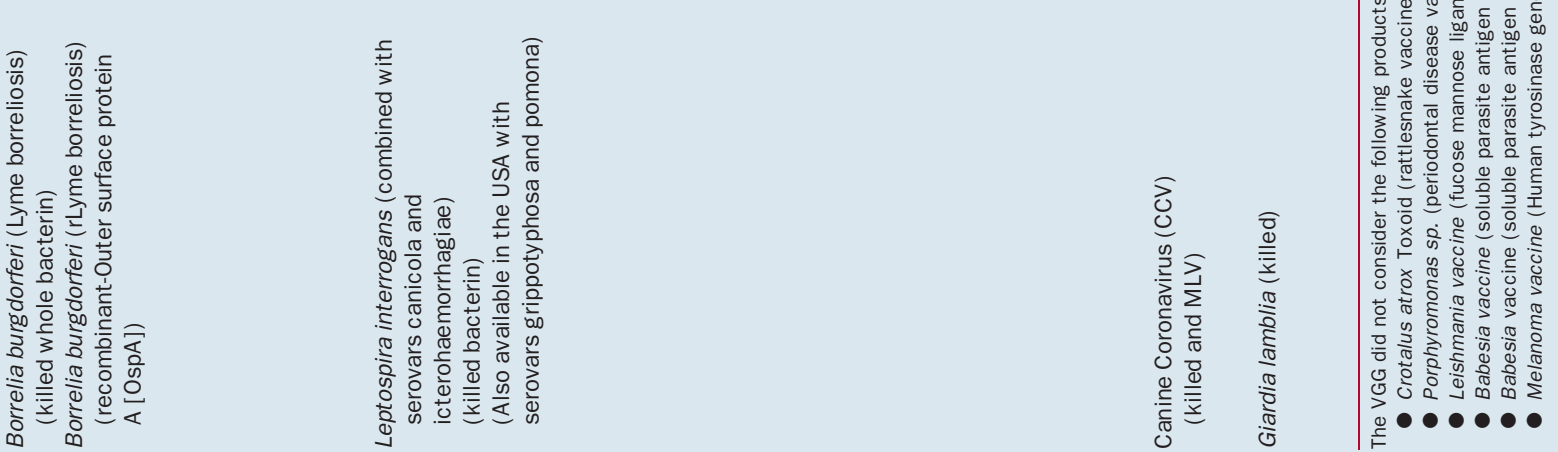


\begin{tabular}{|c|c|c|c|}
\hline $\begin{array}{l}\text { Recommended Vaccines in Various } \\
\text { Combinations (also refer to } \\
\text { Table 1) }\end{array}$ & $\begin{array}{l}\text { Initial Vaccine Series for Puppies } \\
\text { ( }<16 \text { weeks of age) }\end{array}$ & $\begin{array}{l}\text { Initial Vaccine Series for Adults } \\
\text { ( }>16 \text { weeks of age) }\end{array}$ & Comments \\
\hline $\begin{array}{l}\text { Canine Distemper Virus + Canine } \\
\text { Adenovirus- } 2+\text { Canine } \\
\text { Parvovirus (MLV) with or without } \\
\text { Canine Parainfluenza } \\
\text { rCanine Distemper Virus + Canine } \\
\text { Adenovirus- } 2 \text { + Canine } \\
\text { Parvovirus (rCDV + MLV) with or } \\
\text { without Canine Parainfluenza }\end{array}$ & $\begin{array}{l}\text { Administer one dose on admission. } \\
\text { Repeat at 2-week intervals until } \\
16 \text { weeks of age if animal is still } \\
\text { in the facility }\end{array}$ & $\begin{array}{l}\text { Administer one dose on admission. } \\
\text { Repeat in } 2 \text { weeks }\end{array}$ & $\begin{array}{l}\text { Ideally puppies should be } \\
\text { vaccinated beginning at } 6 \text { weeks } \\
\text { of age. Nursing history is not } \\
\text { always available. In the face of } \\
\text { an outbreak, vaccination as early } \\
\text { as } 2-3 \text { weeks (for distemper) or } \\
5 \text { weeks (for parvovirus) may be } \\
\text { indicated }\end{array}$ \\
\hline $\begin{array}{l}\text { Combination product is } \\
\text { administered SQ or IM according } \\
\text { to manufacturer's } \\
\text { recommendations. }\end{array}$ & $\begin{array}{l}\text { Note: Where CDV and/or } \\
\text { parvovirus infection rates are } \\
\text { high, the CDV vaccine may be } \\
\text { administered as early as } 4 \text { weeks } \\
\text { of age but not earlier }\end{array}$ & & $\begin{array}{l}\text { MDA, if present, can interfere with } \\
\text { immunisation }\end{array}$ \\
\hline $\begin{array}{l}\text { Bordetella bronchiseptica } \\
\text { (avirulent live bacterin) }+ \\
\text { Parainfluenza Virus (MLV) } \\
\text { For intranasal use only. Parenteral } \\
\text { administration MUST BE } \\
\text { avoided. }\end{array}$ & $\begin{array}{l}\text { Administer a single dose as early } \\
\text { as } 3 \text { weeks of age. For best } \\
\text { results, if administered prior to } 6 \\
\text { weeks of age, an additional dose } \\
\text { should be given after } 6 \text { weeks of } \\
\text { age }\end{array}$ & $\begin{array}{l}\text { Two doses } 2-4 \text { weeks apart are } \\
\text { recommended }\end{array}$ & $\begin{array}{l}\text { Intranasal (avirulent live) vaccine } \\
\text { is preferred to parenteral vaccine } \\
\text { in puppies because it can safely } \\
\text { be administered to puppies } \\
\text { younger than } 6 \text { weeks. } \\
\text { Additionally a single dose may be } \\
\text { protective }\end{array}$ \\
\hline $\begin{array}{l}\text { Bordetella bronchiseptica } \\
\text { (available as killed bacterin or } \\
\text { antigen extract) } \\
\text { For parenteral administration only }\end{array}$ & $\begin{array}{l}\text { Administer one dose at time of } \\
\text { admission } \\
\text { Administer a second dose 2-4 } \\
\text { weeks later }\end{array}$ & $\begin{array}{l}\text { Two doses } 2-4 \text { weeks apart are } \\
\text { recommended }\end{array}$ & $\begin{array}{l}\text { Topical vaccination in adult dogs or } \\
\text { puppies older than } 16 \text { weeks has } \\
\text { the advantage of providing non- } \\
\text { specific immunity immediately } \\
\text { after vaccination whereas } \\
\text { parenteral does not } \\
\text { Canine respiratory disease complex } \\
\text { (kennel cough) is not a vaccine- } \\
\text { preventable disease and the } \\
\text { vaccine should only be used to } \\
\text { help manage the disease }\end{array}$ \\
\hline Rabies & $\begin{array}{l}\text { If at all, a single dose should be } \\
\text { administered at the time of } \\
\text { discharge from the facility }\end{array}$ & $\begin{array}{l}\text { If at all, a single dose should be } \\
\text { administered at the time of } \\
\text { discharge from the facility }\end{array}$ & $\begin{array}{l}\text { The administration of rabies } \\
\text { vaccine will be determined by } \\
\text { whether the shelter is in } \\
\text { a country in which the disease is } \\
\text { endemic, and by local statute }\end{array}$ \\
\hline
\end{tabular}




\begin{tabular}{|c|c|c|c|c|}
\hline Vaccine & $\begin{array}{l}\text { Initial kitten vaccination } \\
\text { ( } \leq 16 \text { weeks) }\end{array}$ & $\begin{array}{l}\text { Initial adult vaccination } \\
\text { ( }>16 \text { weeks) }\end{array}$ & $\begin{array}{l}\text { Revaccination } \\
\text { recommendation }\end{array}$ & Comments \\
\hline $\begin{array}{l}\text { Panleukopenia Virus (FPV) } \\
\text { (MLV, non-adjuvanted) } \\
\text { Panleukopenia Virus (FPV) } \\
\text { (Killed, adjuvanted; Killed, } \\
\text { non-adjuvanted) } \\
\text { Panleukopenia Virus (FPV) } \\
\text { (MLV, non-adjuvanted; } \\
\text { Intranasal) }\end{array}$ & $\begin{array}{l}\text { Begin at 8-9 weeks of age, } \\
\text { with second dose } 3-4 \\
\text { weeks later, and final } \\
\text { dose at } 16 \text { weeks of age } \\
\text { or later }\end{array}$ & $\begin{array}{l}2 \text { doses, } 3 \text { to } 4 \text { weeks } \\
\text { apart }\end{array}$ & $\begin{array}{l}\text { A single dose is given } 1 \text { year } \\
\text { following the last dose of } \\
\text { the initial series, then no } \\
\text { more frequently than } \\
\text { every } 3 \text { years }\end{array}$ & $\begin{array}{l}\text { Core. Use of MLV vaccines } \\
\text { is not recommended in } \\
\text { pregnant cats and FeLV } \\
\text { and/or FIV infected cats. } \\
\text { Killed vaccines may be } \\
\text { more appropriate in } \\
\text { disease-free colonies as } \\
\text { there is no risk of spread } \\
\text { or reversion to virulence. } \\
\text { Intranasal vaccination } \\
\text { may not be as effective as } \\
\text { injectable vaccination in } \\
\text { high-risk environments } \\
\text { where exposure may } \\
\text { occur soon after } \\
\text { vaccination }\end{array}$ \\
\hline $\begin{array}{l}\text { Feline Herpesvirus-1 (FHV-1) } \\
\text { (MLV, non-adjuvanted) } \\
\text { Feline Herpesvirus-1 (FHV-1) } \\
\text { (Killed, adjuvanted) }\end{array}$ & $\begin{array}{l}\text { Begin at 8-9 weeks of age, } \\
\text { with second dose } 3-4 \\
\text { weeks later, and final } \\
\text { dose at } 16 \text { weeks of age } \\
\text { or later }\end{array}$ & $\begin{array}{l}2 \text { doses, } 3 \text { to } 4 \text { weeks } \\
\text { apart }\end{array}$ & $\begin{array}{l}\text { A single dose is given } 1 \text { year } \\
\text { following the last dose of } \\
\text { the initial series, then } \\
\text { every } 3 \text { years }\end{array}$ & $\begin{array}{l}\text { Core. MLV FHV-1/FCV } \\
\text { vaccines are invariably } \\
\text { combined with each } \\
\text { other, either as bivalent } \\
\text { products or in } \\
\text { combination with } \\
\text { additional vaccine } \\
\text { antigens. Upper } \\
\text { respiratory disease signs } \\
\text { are more commonly seen } \\
\text { following intranasal } \\
\text { vaccination }\end{array}$ \\
\hline $\begin{array}{l}\text { Feline calicivirus (FCV) } \\
\text { (MLV, non-adjuvanted) } \\
\text { Feline calcivirus (FCV) } \\
\text { (Killed, adjuvanted) }\end{array}$ & $\begin{array}{l}\text { Begin at 8-9 weeks of age, } \\
\text { with second dose } 3-4 \\
\text { weeks later, and final } \\
\text { dose at } 16 \text { weeks of age } \\
\text { or later }\end{array}$ & $\begin{array}{l}2 \text { doses, } 3 \text { to } 4 \text { weeks } \\
\text { apart }\end{array}$ & $\begin{array}{l}\text { A single dose is given } 1 \text { year } \\
\text { following the last dose of } \\
\text { the initial series, then } \\
\text { every } 3 \text { years }\end{array}$ & $\begin{array}{l}\text { Core. MLV FHV-1/FCV } \\
\text { vaccines are invariably } \\
\text { combined with each } \\
\text { other, either as bivalent } \\
\text { products or in } \\
\text { combination with } \\
\text { additional vaccine } \\
\text { antigens. Upper } \\
\text { respiratory disease signs } \\
\text { are more commonly seen } \\
\text { following intranasal } \\
\text { vaccination }\end{array}$ \\
\hline $\begin{array}{l}\text { Rabies (Canarypox virus- } \\
\text { vectored recombinant, } \\
\text { non-adjuvanted) }\end{array}$ & $\begin{array}{l}\text { Administer a single dose as } \\
\text { early as } 8 \text { weeks of age, } \\
\text { with revaccination } 1 \text { year } \\
\text { later }\end{array}$ & $\begin{array}{l}\text { Administer } 2 \text { doses, } \\
12 \text { months apart }\end{array}$ & Annual booster is required & $\begin{array}{l}\text { Non-core except where } \\
\text { required by statute (e.g. } \\
\text { for pet travel) or in areas } \\
\text { where the disease is } \\
\text { endemic }\end{array}$ \\
\hline $\begin{array}{l}\text { Rabies ( } 1,3 \text { and } 4 \text { year } \\
\text { killed, adjuvanted } \\
\text { products are available) }\end{array}$ & $\begin{array}{l}\text { Administer a single dose as } \\
\text { early as } 12 \text { weeks of age, } \\
\text { with revaccination } 1 \text { year } \\
\text { later }\end{array}$ & $\begin{array}{l}\text { Administer } 2 \text { doses, } \\
12 \text { months apart }\end{array}$ & $\begin{array}{l}\text { Booster as per licensed } \\
\text { DOI }\end{array}$ & $\begin{array}{l}\text { Non-core except where } \\
\text { required by statute (e.g. } \\
\text { for pet travel) or in areas } \\
\text { where the disease is } \\
\text { endemic }\end{array}$ \\
\hline $\begin{array}{l}\text { Feline Leukemia Virus } \\
\text { (FeLV) (Canarypox virus- } \\
\text { vectored recombinant, } \\
\text { non-adjuvanted, } \\
\text { transdermal USA and } \\
\text { injectable elsewhere) }\end{array}$ & $\begin{array}{l}\text { Administer an initial dose as } \\
\text { early as } 8 \text { weeks of age; } \\
\text { a second dose should be } \\
\text { administered 3-4 weeks } \\
\text { later }\end{array}$ & $\begin{array}{l}2 \text { doses, } 3 \text { to } 4 \text { weeks } \\
\text { apart }\end{array}$ & $\begin{array}{l}\text { When indicated a single } \\
\text { dose is given } 1 \text { year } \\
\text { following the last dose of } \\
\text { the initial series, then } \\
\text { annually in cats } \\
\text { determined to have } \\
\text { sustained risk of exposure }\end{array}$ & $\begin{array}{l}\text { Non-core. In the United } \\
\text { States, the } 0.25 \mathrm{ml} \text { rFeLV } \\
\text { vaccine dose may only be } \\
\text { administered via the } \\
\text { manufacturer's } \\
\text { transdermal } \\
\text { administration system. } \\
\text { Only FeLV negative cats } \\
\text { should be vaccinated. } \\
\text { FeLV testing prior to } \\
\text { vaccine administration } \\
\text { should be mandatory }\end{array}$ \\
\hline
\end{tabular}




\begin{tabular}{|c|c|c|c|c|}
\hline Vaccine & $\begin{array}{l}\text { Initial kitten vaccination } \\
\text { ( } \leq 16 \text { weeks) }\end{array}$ & $\begin{array}{l}\text { Initial adult vaccination } \\
\quad \text { ( }>16 \text { weeks) }\end{array}$ & $\begin{array}{l}\text { Revaccination } \\
\text { recommendation }\end{array}$ & Comments \\
\hline $\begin{array}{l}\text { Feline Leukemia Virus } \\
\text { (FeLV) (Killed, } \\
\text { adjuvanted) } \\
\text { Feline Leukemia Virus } \\
\text { (FeLV) (recombinant } \\
\text { protein subunit, } \\
\text { adjuvanted) }\end{array}$ & $\begin{array}{l}\text { Administer an initial dose as } \\
\text { early as } 8 \text { weeks of age; } \\
\text { a second dose should be } \\
\text { administered 3-4 weeks } \\
\text { later }\end{array}$ & $\begin{array}{l}2 \text { doses, } 3 \text { to } 4 \text { weeks } \\
\text { apart }\end{array}$ & $\begin{array}{l}\text { When indicated, a single } \\
\text { dose is given } 1 \text { year } \\
\text { following the last dose of } \\
\text { the initial series, then } \\
\text { annually in cats } \\
\text { determined to have } \\
\text { sustained risk of exposure }\end{array}$ & $\begin{array}{l}\text { Non-core. Only FeLV } \\
\text { negative cats should be } \\
\text { vaccinated. FeLV testing } \\
\text { prior to vaccine } \\
\text { administration should be } \\
\text { mandatory }\end{array}$ \\
\hline $\begin{array}{l}\text { Feline Immunodeficiency } \\
\text { Virus (FIV) (Killed, } \\
\text { adjuvanted) }\end{array}$ & $\begin{array}{l}3 \text { doses are required: } \\
\text { The initial dose is } \\
\text { administered as early as } 8 \\
\text { weeks of age; } 2 \\
\text { subsequent doses should } \\
\text { be administered at an } \\
\text { interval of } 2-3 \text { weeks }\end{array}$ & $\begin{array}{l}3 \text { doses are required: } \\
\text { Each dose is administered } \\
2-3 \text { weeks apart }\end{array}$ & $\begin{array}{l}\text { When indicated, a single } \\
\text { dose is given } 1 \text { year } \\
\text { following the last dose of } \\
\text { the initial series, then } \\
\text { annually in cats } \\
\text { determined to have } \\
\text { sustained risk of } \\
\text { exposure }\end{array}$ & $\begin{array}{l}\text { Not recommended. } \\
\text { Vaccination induces } \\
\text { production of antibodies } \\
\text { indistinguishable from } \\
\text { those developed in } \\
\text { response to FIV infection, } \\
\text { and interferes with all } \\
\text { antibody-based FIV } \\
\text { diagnostic tests for at } \\
\text { least a year following } \\
\text { vaccination }\end{array}$ \\
\hline $\begin{array}{l}\text { Feline Infectious Peritonitis } \\
\text { (FIP) (MLV, non- } \\
\text { adjuvanted, intranasal) }\end{array}$ & $\begin{array}{l}\text { Administer a single dose as } \\
\text { early as } 16 \text { weeks of age, } \\
\text { and a second dose } 3-4 \\
\text { weeks later }\end{array}$ & $\begin{array}{l}2 \text { doses, 3-4 weeks } \\
\text { apart }\end{array}$ & $\begin{array}{l}\text { Annual booster is } \\
\text { recommended by the } \\
\text { manufacturer }\end{array}$ & $\begin{array}{l}\text { Not Recommended. } \\
\text { According to the limited } \\
\text { studies available, only } \\
\text { cats known to be feline } \\
\text { coronavirus antibody } \\
\text { negative at the time of } \\
\text { vaccination are likely to } \\
\text { develop some level of } \\
\text { protection }\end{array}$ \\
\hline $\begin{array}{l}\text { Chlamydophila felis } \\
\text { (Avirulent live, non- } \\
\text { adjuvanted) } \\
\text { Chlamydophila felis (Killed, } \\
\text { adjuvanted) }\end{array}$ & $\begin{array}{l}\text { Administer the initial dose } \\
\text { as early as } 9 \text { weeks of } \\
\text { age; a second dose is } \\
\text { administered 3-4 weeks } \\
\text { later }\end{array}$ & $\begin{array}{l}\text { Administer } 2 \text { doses, 3-4 } \\
\text { weeks apart }\end{array}$ & $\begin{array}{l}\text { Annual booster is indicated } \\
\text { for cats with sustained } \\
\text { exposure risk }\end{array}$ & $\begin{array}{l}\text { Non-core. Vaccination is } \\
\text { most appropriately used } \\
\text { as part of a control } \\
\text { regime for cats in } \\
\text { multiple-cats } \\
\text { environments where } \\
\text { infections associated with } \\
\text { clinical disease have been } \\
\text { confirmed. Inadvertent } \\
\text { conjunctival inoculation } \\
\text { of vaccine has been } \\
\text { reported to cause clinical } \\
\text { signs of infection. These } \\
\text { vaccines may be } \\
\text { associated with adverse } \\
\text { reactions (hypersensitivity) }\end{array}$ \\
\hline $\begin{array}{l}\text { Bordetella bronchiseptica } \\
\text { (Avirulent live, non- } \\
\text { adjuvanted, intranasal) }\end{array}$ & $\begin{array}{l}\text { Administer a single dose } \\
\text { intranasally as early as } 8 \\
\text { weeks of age }\end{array}$ & $\begin{array}{l}\text { Administer a single dose } \\
\text { intranasally }\end{array}$ & $\begin{array}{l}\text { Annual booster is indicated } \\
\text { for cats with sustained } \\
\text { risk }\end{array}$ & $\begin{array}{l}\text { Non-Core. Vaccination may } \\
\text { be considered in cases } \\
\text { where cats are likely to } \\
\text { be at specific risk of } \\
\text { infection }\end{array}$ \\
\hline $\begin{array}{l}\text { Feline Giardia (Killed, } \\
\text { adjuvanted) }\end{array}$ & $\begin{array}{l}\text { Administer a single dose at } \\
8 \text { weeks of age; a second } \\
\text { dose is administered } 2-4 \\
\text { weeks later }\end{array}$ & $\begin{array}{l}2 \text { doses, } 2-4 \text { weeks } \\
\text { apart }\end{array}$ & $\begin{array}{l}\text { Annual booster is } \\
\text { recommended by the } \\
\text { manufacturer }\end{array}$ & $\begin{array}{l}\text { Not Recommended. There } \\
\text { are insufficient studies } \\
\text { available to support the } \\
\text { role of Giardia vaccination } \\
\text { in preventing clinical } \\
\text { signs of disease in cats }\end{array}$ \\
\hline
\end{tabular}




\begin{tabular}{|c|c|c|c|}
\hline Vaccine & Kittens ( $\leq 16$ weeks) & $\begin{array}{l}\text { Adult and Adolescent } \\
\qquad>16 \text { weeks) }\end{array}$ & Comments \\
\hline $\begin{array}{l}\text { Panleukopenia Virus (FPV) } \\
\text { Feline Herpesvirus-1 (FHV-1) } \\
\text { Feline Calicivirus (FCV) }\end{array}$ & $\begin{array}{l}\text { Administer a single dose at the } \\
\text { time of admission as early as } \\
4 \text { to } 6 \text { weeks of age; then, every } \\
2-4 \text { weeks until } 16 \text { weeks of } \\
\text { age if still in the facility } \\
\text { The earlier recommended age ( } 4 \\
\text { weeks) and short end of the } \\
\text { interval ( } 2 \text { weeks) should be } \\
\text { used in very high risk } \\
\text { environments or during } \\
\text { outbreaks }\end{array}$ & $\begin{array}{l}\text { Administer a single dose at the } \\
\text { time of admission; repeat in } 2-4 \\
\text { weeks }\end{array}$ & $\begin{array}{l}\text { MLV preparations are preferable. } \\
\text { Use of intranasal FPV vaccines is } \\
\text { generally not recommended in } \\
\text { the shelter environment. Use of } \\
\text { intranasal FCV/FHV-1 MLV } \\
\text { vaccines may be preferable when } \\
\text { rapid onset ( } 48 \text { hrs) of immunity } \\
\text { is important. Post-vaccinal } \\
\text { sneezing, more commonly seen } \\
\text { following administration of } \\
\text { intranasal FCV/FHV-1 vaccine, } \\
\text { may be impossible to distinguish } \\
\text { from active infection }\end{array}$ \\
\hline Rabies & $\begin{array}{l}\text { If at all, a single dose should be } \\
\text { administered at the time of } \\
\text { discharge from the facility }\end{array}$ & $\begin{array}{l}\text { If at all, a single dose should be } \\
\text { administered at the time of } \\
\text { discharge from the facility }\end{array}$ & $\begin{array}{l}\text { The administration of rabies } \\
\text { vaccine will be determined by } \\
\text { whether the shelter is in } \\
\text { a country in which the disease is } \\
\text { endemic, and by local statute }\end{array}$ \\
\hline
\end{tabular}

\section{NOTE}

The version of these guidelines printed in this issue of the Journal of Small Animal Practice includes only the main text and tables of the guidelines document. The original document also includes (as appendices) individual fact sheets for the core canine and feline vaccines, and a series of frequently asked questions on canine and feline vaccination. It is hoped to print these in a subsequent edition of the journal but, from September 2007, the entire VGG document will be available on the WSAVA web-site - http://www.wsava.org

These WSAVA vaccination guidelines are reproduced here with permission from Dr Brian Romberg, President of the WSAVA. 